\title{
GUSZMANN GERGELY
}

\section{A HINDU NACIONALIZMUS HOMOGENIZÁLÓ TÖREKVÉSEI}

\section{Narendra Modi politikai örökségének megkonstruálása}

Ebben a fejezetben kísérletet teszünk arra, hogy bemutassuk a Baratija Dzsanata Párt (BJP) nemzetépítő törekvéseit és azok mögöttes tartalmát, valamint rávilágítsunk, hogy miként használták föl az egység (számukra hindu egység) megteremtésének érdekében korábbi politikai szereplők érdemeit, mint például India első belügyminiszterének, Sardar Vallabhbhai Patelnek a történelmi szerepét. A választásunk azért esett Patel személyére, mivel az ő példáján keresztül lehet talán a legérzékletesebben bemutatni azt a folyamatot, amely révén a BJP rátelepszik más politikai örökségére vagy történetiségére. A BJP közéleti retorikája gyakran egyfajta öncélú szinkretista politikai attitűdben nyilvánult meg, amely a - rokkani értelemben vett - politikai törésvonalak hatásait kihasználva a minél szélesebb körű társadalmi legitimáció megteremtésére törekedett. Ez a legitimáció a BJP esetében egyértelműen a hindu többség hangsúlyozását jelentette, és azt az ambíciót szolgálta, hogy egy kollektív identitás létrehozásával politikai hegemóniát gyakoroljon a Kongresszus Párt fölött. Sardar Patel és a BJP politikai cselekedeteinek összemosása lokális és nemzeti szinten zajlott. Nem állíthatjuk, hogy vizsgálatunk minden részletre kiterjedően képes bemutatni a hindu nacionalista kormányzat történeti anakronizmusát, de választ kaphatunk arra a kérdésre: hogyan próbálták meg Sardar Patel történeti-politikai örökségét kisajátítani, és milyen hindu soviniszta érdekeket próbáltak meg Patel nevének felhasználásával elfogadtatni a közvéleménnyel.

A hindu nacionalista vonal idealista államférfi-eszményképe a Nehruval szemben ellentétes álláspontot, vagyis egy hindu állam megteremtését képviselő politikus volt. Habár ezt a képet nem teljesen fedi Sardar Patel történeti szerepvállalása, mégis benne vélték felfedezni az egységes hindu India államférfijét. A BJP szerint Patel lett volna a megfelelő személy a független India első miniszterelnökének.

A hindu nacionalisták historizáló diskurzusa alapján Patel a függetlenségi harcban hasonló jelentőségű, sőt tetteiben és erényeiben pozitívabb szereplő volt, mint Nehru vagy más kongresszus párti vezetők, akik kompromisszumra törekvő, megalkuvó és populista politikájukkal beárnyékolták India első belügyminiszterének dicsőségét. Patel portréjának megrajzolásakor az államférfit a

1 A tanulmány elkészítését az EFOP-3.6.1-16-2016-00001. „Kutatási kapacitások és szolgáltatások komplex fejlesztése az Eszterházy Károly Egyetemen" című pályázat támogatta. 
"hindu" India hiteles vezetőjeként ábrázolták, aki az elszakadás idején kemény kézzel megvédte a hindukat a muszlim agressziótól, míg Nehru és Gandhi szemet hunytak a kisebbségi érdekek előtérbe kerülése fölött. Kétségkívül India függetlenségén munkálkodva számos ponton különbözött Vallabhbhai Patel, Jawaharlal Nehru és M. K. Gandhi álláspontja, s Patel az utolsó pillanatig ellenezte Pakisztán elszakadását Indiától. A véleménykülönbségek ellenére ő vezényelte le az elszakadás gyakorlati részét, és igyekezett minden lehetséges eszközzel (akár erőszak alkalmazásával is) megőrizni India integritását. Azok a kényszerek, amelyek India egységének körvonalazása során felmerültek, és amelyeket mint India egyik befolyásos és felelősségteljes politikusának magára kellett vállalnia, nem akadályozták meg abban, hogy saját belátása szerint, minimális kompromisszumokkal hajtsa végre elképzeléseit. ${ }^{2}$

A BJP Patelt muszlimellenesnek nyilvánította, de ezt inkább erénynek látta, semmint vezetői jellemhibának vagy értéktelített politikai attitűdnek. A BJPvezetők arra a szelektív emlékezetre építettek, amely Patelnek mint a hinduk védelmezőjének és a muszlim érdekekkel intenzíven szembeszálló, az indiai egységet létrehozó, államférfinak állított szobrot. Az általunk vizsgált esetben Narendra Modi, India jelenlegi miniszterelnöke, Gudzsarát állam akkori főminisztere (Chief minister) a Tribune India és más indiai napilap hasábjain megjelent cikkek szerint választási beszédeiben és nyilatkozataiban saját magát Sardar Patel történeti inkarnációjának nevezte, és nyíltan hirdette, hogy rokonszenvezik az egykori belügyminiszter nézeteivel. ${ }^{3}$ Itt nem csupán egy választási beszéd vagy kampány elemzését kívánjuk bemutatni, sokkal inkább azt a politikai folyamatot, amely a Gudzsarát állam emlékezetébe ivódott múltat (Sardar Patel mint a függetlenségi harc egyik főszereplője és India egységének megteremtője) használja fel, manipulálja és hamisítja az aktuális politikai érdek szerint. A sajtóban megjelent híradások és kritikai álláspontok közül leginkább a neves kolumnista Venkatraman Gangadhar Narendra Modi as Sardar Patel, An odious comparison, a strange claim című cikkét vesszük alapul, mivel ez az írás mutatja be talán legérzékletesebben, milyen torzított és történetietlen tükörben szemlélte Sardar Patel képét a választási siker érdekében magát Patel örököseként feltüntető Narendra Modi. ${ }^{4}$

2 Sardar Patelről bővebben: Guszmann Gergely: A független India architektúrája (Sardar Vallabhbhai Patel szerepe az Indiai Kongresszusban és az 1947-es integrációs folyamatokban). In: Acta Universitatis de Carolo Eszterházy Nominatae. Sectio Historiae Nova Series Tom. XXXVII. Szerk. Miskei Antal. Eger 2010. 257-273.

3 A helyi kampányuk sikere érdekében a BJP Sardar Patel történeti alakját igyekezett felhasználni, mivel Patel helyi születésű, és emléke élénken él a gudzsaráti társadalomban.

4 Úgy gondoljuk érdemes részletesebb foglalkozni a cikk mondanivalójával, mivel a politikai események bemutatásán túl részletesen foglalkozik Sardar Patel emlékezetének továbbélésével és a róla szóló politikai diskurzusok konfrontációival. Venkatraman Gangadhar: Narendra Modi as Sardar Patel, An odious comparison, a strange claim. The Tribune India, Chandigarh, 2002. november 13. 10-14. 
Gangadhar cikkének vezérmotívuma alapján a 2002-es helyi választásokon a BJP egyfajta örökösödési versenyt indított Sardar Patel politikai hagyatékáért, és negligálva azt a történeti tényt, hogy Patel egész karrierje során a Kongresszus Párt vezetőségéhez tartozott, kialakítottak egy pro-hindu Patel jelentésváltozatot. Nem állíthatjuk, hogy a függetlenségi harc és India egységesítésének története során nem fordult volna elő, hogy Patel kinyilvánította hindu vallásosságát, de ez soha nem befolyásolta döntéseiben, és semmilyen jelét nem adta annak, hogy támogatta volna az akkori Rashtriya Swayamsevak Sangh (Nemzeti Önkéntesek Szövetsége, RSS) szélsőséges muszlimellenes tevékenységét. Amikor fény derült Nathuram Godse kapcsolatára a hindu radikális nacionalista mozgalmakkal (vagy azok vezetőségével), Patel volt az, aki csírájában akarta elfojtani a merénylet utáni vallásközösségi (communal) zavargásokat, és betiltotta az RSS működését. Hiteltelennek tűnik tehát, hogy az RSS-el nyíltan szoros kapcsolatot ápoló BJP kontinuitást látott Sardar Patel és Narendra Modi politikai céljai között. ${ }^{5}$ Sokkal inkább kivehető a BJP azon szándéka, hogy a kollektív emlékezetben pozitív figuraként tovább élő, ünnepelt államférfi bőrébe bújva meggyőzze a választókat arról, hogy szavazatukkal Sardar Patel széles társadalmi körben elismert tetteivel azonosulnak, és követik azokat, akik a grand homme nyomdokaiban lépkednek.

A folyamat lényege egyrészt egyértelműen Sardar Patel politikai hagyatékának kisajátítása, másrészt egy lokális identitás kialakítása, amelyben Patel múltbéli nemzetépítő cselekedetei (vagy azok hatásai) és a BJP jelenkori politikai nézetei összeérni látszanak. Patel politikai, kulturális és társadalmi munkájának ismeretében ugyanakkor kijelenthető, hogy a BJP ennek az örökségnek csupán egy részét emelte be saját programjába, ezzel tovább torzítva a Sardar Patelról folytatott diskurzust. Azzal pedig, hogy Narendra Modi Patelt a hindu érdekek és a „vallás igaz megváltójának" nevezte, egy újabb fogalmi zavart generált, mivel Patel hindusága csakugyan megmutatkozott, mikor (példának okáért) a tolerancia, elfogadás és békés egymás mellett élés jegyében felszólította az indiai lakosságot a vallásközösségi erőszak befejezésére, de nem abban az értelemben, ami a hindu szupremáciát jelentette volna a kisebbség fölött. Modi itt a hindu alatt az inkább politikai, semmint teológiai, Hindutva kifejezést értette, amely egy hindu nacionalista konstrukció, és sem Patel, sem az akkori hindu nacionalista mozgalmak nem használták a pateli politika leírására. Ezzel Modi lényegében dekontextualizálta Patel nemzetépítő tevékenységét, és egy olyan értelmezési mezőt konstruált, amely effektíve semmilyen közéleti narratívában nem létezett. V. Gangadhar keserűen meg is jegyezte cikke végén, hogy mindezek ellenére Narendra Modi teljes mértékben élvezte a gudzsaráti hinduk bizalmát.7 Maga a Patelről kialakított BJP interpretáció lehetett torz vagy történetietlen, de mint politikai koncepció eredményesen működött, és meg-

\footnotetext{
5 V. Gangadhar: Narendra Modi as Sardar Patel. i. m. 12.

6 V. Gangadhar: Narendra Modi as Sardar Patel. i. m. 13.

7 V. Gangadhar: Narendra Modi as Sardar Patel. i. m. 14.
} 
hozta a választási diadalt Narendra Modi számára. A 2002. október 15-én aratott gudzsaráti választási győzelem lehetővé tette Modi számára, hogy teljesen újjászervezze az állami közigazgatást, és még tovább növelje a BJP helyi befolyását. ${ }^{8}$ Ezzel az eredménnyel Modi nem csupán megállította az 1999 óta egyre inkább népszerütlen BJP hanyatlását, és sikerült Gudzsarát államot majdnem teljes egészében „sáfrány színűre” festenie, hanem a legnépszerűbb (és egyben a sajtóban talán máig legvitatottabb) BJP-politikussá lépett elő a túlnyomórészt hindu lakta területeken. A Tribune India tudósítása alapján a választási eredmények kiszivárgása közben Gandinagár utcáit ellepte a sáfrány színú sálat viselő aktivisták csoportja, és ünnepi hangulatban édességet osztottak a járókelőknek. ${ }^{9}$

Modi több körzetbe is ellátogatott, és találkozott követőivel, akik táncolva fogadták a földcsuszamlásszerű győzelem első számú emberét. Modi híveihez intézett beszédében megjegyezte, hogy ez volt az első olyan választás, ahol a Kongresszus kénytelen volt elismerni Sardar Patel elsőbbségét Jawaharlal Nehru fölött. A BJP győzelme és Patel múltbéli érdemei között Modi megpróbált kapcsolatot teremteni és egyfajta szakralitást adni a folyamatnak, mert szerinte jelentősége, sőt üzenete volt annak, hogy a kampányt Patel születésnapján (október 31.) kezdték meg Karamsandban (Patel szülővárosa), és halála napjának évfordulóján (december 15.) arattak diadalt. ${ }^{10}$ A siker titkát fürkésző kérdésekre Modi azzal válaszolt, hogy ez nem egy párt, hanem a gudzsaráti büszkeség és 50 millió gudzsaráti polgár győzelme. ${ }^{11}$ A politikai retorikán túl feltételezhetjük azt, hogy Modi tudatában volt a gudzsaráti hindu tömegek vallásosságának, és egészen egyszerűen kijátszotta a hindu kártyát. A kampányidőszakban beszédeivel tovább erősítette a hindu vallásos identitást, és új egységesítő dimenziót is kölcsönzött neki azzal, hogy Sardar Patel történeti emlékét a hindu identitás részévé tette. ${ }^{12} \mathrm{~A}$ központi problematika tehát továbbra is a múlt, Sardar Patel emlékezetének felhasználása a vallásos töme-

8 A BJP a helyi törvényhozó testületben 117-ről 126-ra növelte a taglétszámát (182 az összlétszám), amíg a legnagyobb ellenzéki pártnak, az Indiai Kongresszus Pártnak, csupán 51 szék jutott. Igy a BJP 2/3-os elsöprő többséggel rendelkezett az állami szintű törvényhozásban és kinevezett miniszterei révén a végrehajtásban is.

9 A helyi választások, valamint Modi kampányának és a múlt politikai felhasználásának sikerét jelzi, hogy hasonló eszközökkel sikerült 2014-ben leváltania a kormányt. Modi egy olyan erődemonstrációnak szánta a gudzsaráti választásokat, amellyel előkészítheti a közelgő országos választásokat. Az első miniszterelnöksége idején Modi hű maradt korábbi elképzeléseihez, és folytatta Sardar Patel történeti alakjának beemelését a független India politikai krédójába. Habár Patel korábban is népszerűségnek örvendett a gudzsaráti hinduk körében, de Modi volt az, aki nemzeti szintre emelte örökségét.

10 Prashant Sood: Cong blames defeat on Hindutva wave. Tribune India, Ahmedabad, 2002. december 15.

11 Gudzsarát lakossága: 60, 439, 692. Forrás: http://statisticstimes.com/demographics/ india/gujarat-population.php (2020. 10. 15.)

12 P. Sood: Cong blames defeat. i. m. 
gek mobilizálása céljából, ami polarizálta az amúgy is megosztott helyi társadalmat. Mivel a meglehetősen tradicionalista indiai társadalomban problémás lett volna egy merőben újfajta politikai program kidolgozása, valamint hatékony azonosulási pontok létrehozása az állampolgárok számára, már a kampány kezdetekor a BJP a múlt átformálására vagy még inkább: kisajátítására helyezte a hangsúlyt. Sardar Patel alakjának közvetlen politikai eszközzé alakítása során a következményeinek és mellékhatásainak gondolata fel sem merült egyik felelős BJP-politikus fejében sem, mivel egyrészt a közvélemény őrködő szerepét nem találták befolyásoló tényezőnek, másrészt a hindu és nem hindu tömegek közti feszültséget egyelőre hasznosíthatónak vélték. Az indiai napilapok hasábjain megjelenő túlnyomórészt kritikus és figyelmeztető írások nem jutottak el a választókig, mivel a BJP kampányhadjárata és vezetőinek mozgósító beszédeitől hangos körútja egy sokkal személyesebb kapcsolatot tudott létesíteni az emberekkel, mint a nyomtatott sajtó.

Annak érdekében, hogy a párt minél közvetlenebb módon eljusson a választókhoz, Modi ún. "gaurav yatra"-kat,13 avagy a gudzsaráti büszkeség feltámasztását, visszaállítását célzó zarándoklatszerü, az egész országot átszelő körmeneteket szervezett. A felvonulásnak és magának a Modi által kezdeményezett, decemberre előrehozott állami szintű választásoknak valójában a 2002. február 27-i vonatmerénylet és az azt követő vallásközösségi (communal) zavargások utáni társadalmi bizonytalanság adta meg az alkalmat. Az Ajódjába hindu aktivistákat szállító vonatot a Gudzsarát állambeli Godra városában felgyújtották, aminek következtében 58-an (főként gyerekek és nők) az életüket vesztették. A tragédiát követően Gudzsarát számos pontján zavargások és muszlimellenes atrocitások törtek ki, és több mint 2000-en (föleg muszlimok) haltak meg a pogromokban. A Modi-kormányzat és a helyi rendőrség felelőssége az erőszakos cselekmények eszkalálódásában kérdésessé vált, mivel a hatalmi szervek hathatós beavatkozása nélkül két hónapon keresztül tombolt a vérengzés. ${ }^{14} \mathrm{Az}$ ellenzéki pártok Modi lemondását követelték, aki erre válaszként kérelmezte az új választásokat, hogy visszaállítsa renoméját, és megmutassa, még mindig élvezi a gudzsarátiak bizalmát. A BJP szóvivője, Mukhtar Abbas Naqvi szerint az ellenzéki pártok propagandájának és nem a zavargásoknak volt köszönhető, hogy a gudzsaráti kormányról negatív kép alakult ki a médiában. Naqvi azzal vádolta az ellenzéket, hogy a sajtóban tett kijelentéseikkel átpolitizálták a zavargásokat, és a gudzsaráti emberek kollektív bűneként tüntették föl. ${ }^{15}$

13 "Gaurav yatra" (büszkeség menet) Paghvel: Modi kicks off Gujarat Gaurav Yatra, The Times of India, 2002. szeptember 18. Forrás: http://timesofindia.indiatimes.com/articleshow/21590967.cms?utm_source=contentofinterest\&utm_medium=text\&utm_ campaign=cppst (Letöltve: $20 \overline{2} 0.10 .16$.

14 Gujarat's voters could decide the future of the whole country's government. The Economist, Ahmedebad, 2002. december 5.

15 BJP picks riot-hit Kheda to launch Modi pride parade. The Indian Express, Ahmedabad/ New Delhi, 2002. auguzstus 21. Forrás: http://archive.indianexpress.com/oldStory/8003/ (Letöltve: 2002. 10. 16.) 
A gaurav yatra felvonulásokra a BJP szerint szükség volt a párt megtépázott pozíciójának, valamint a gudzsaráti emberek büszkeségének (és a negatív ellenzéki propaganda okozta károknak) helyreállítása céljából. A párt augusztus 20-án jelentette be, hogy a yatra első állomása szeptember 3-án Kedában lesz megtartva, mivel ott voltak a legsúlyosabb harcok a hindu és a muszlim közösségek között. A közel másfél hónaposra tervezett „büszkeség menet” létjogosultsága már júliusban az ellenzéki pártok kereszttüzébe került, mivel féltek, hogy ez a fajta direkt, vallási érzületre ható politikai kampány csak olaj a túzre, és egy újabb vallásközösségi (communal) erőszakhullámot válthat ki. A BJP gudzsaráti vezetője, Rajendra Singh Rana a menetet a vallásos Jagannatha Yatra fesztiválhoz hasonlította, amely a hindu közösségekben, főleg Dzsaganát Puriban, Orissza államban népszerü és örömteli ünnepnek számít. Rana ugyanakkor hozzáfüzte, hogy a gaurav yatra a választási kampány keretén belül fog elindulni, és nem lesz vallásos felhangja. ${ }^{16}$ Ezt az ellentmondást nem sikerült feloldaniuk a yatra szervezőinek, mert vegyítve jelentek meg abban vallásos és pártszimbólumok.

A hindu vallási és pártjelképekkel kevert felvonulások menete nagyjából mindenhol ugyanúgy zajlott, vagyis először vallásos dalokat játszottak, majd Modi, Rana és más BJP-vezetők mondtak beszédeket, amelyek elsősorban a hindu közösségek erejéről szóltak, és/vagy a Kongresszus Párt vezetőjét, Sonia Gandhit, valamint Pervez Musharraf pakisztáni elnököt kritizálták. ${ }^{17}$ A beszédeket követően éjszakába nyúló zenei előadás következett, amelyet a tömegek általában kitörő örömmel fogadtak, de a sajtó sem tudósított rendbontásról egy esetben sem. Talán érdemes megjegyezni ugyanakkor, hogy Modi egyik beszédében (szeptember 9.) muszlimellenes kijelentéseket tett, amelyeket a yatra vezetője, Jayanta Baroti később tagadott, de az előkerült hangfelvételek, ${ }^{18}$ ha mást nem is igazoltak, de ellentmondásosnak mutatták Modi szavait.19 Azért tartjuk lényegesnek kiemelni, hogy a felvonulások szervezetten és a társadalmi viszonyokhoz mérten békésen zajlottak, mert a BJP-nek egyáltalán nem állt érdekében, hogy egy újabb erőszakhullámot robbantson ki. Modi a szeptember 9-i szerencsétlenül megfogalmazott és kisebbségellenesnek érthető beszédét igyekezett korrigálni. A szeptember második felében indult újabb yatra alkalmával ugyanis az indiai nemzet egységének kifejezése céljából megjegyezte, hogy a hinduk és muszlimok együttes erővel harcoltak a brit uralom ellen, és közösen vívták ki India függetlenségét. ${ }^{20} \mathrm{Az}$ egyensúlyozó politikai retorika ellenére a gaurav yatra nem tudta a

16 The Indian Express, Ahmedabad/New Delhi, 2002. augusztus 21.

17 Sudhir Vyas: Crowd caned after CM's yatra speech at Morbi. The Times of India, Ahmedabad, 2002. október 29.

18 Modi's anti-minority speech aired, Gujarat Govt sees Opposition hand. The Indian Express, Ahmedabad/New Delhi, 2002. szeptember 15.

19 Snubbed, Modi sticks to safe topics. The Indian Express, Ahmedabad/New Delhi, 2002. szeptember 11.

20 Modi launches second phase of Gaurav Yatra, The Times of India, Ahmedabad, 2002. szeptember 14 . 
poszt-godrai helyzetet stabilizálni, és azzal, hogy a gyűléseken gyakran a „Godra, Godra" szavakat skandálták - ami egyértelműen a merényletben meghalt hinduk tragédiáját ültette el újra és újra a kommunikatív emlékezetben -, csak tovább szították a hinduk és a muszlimok közti indulatokat. ${ }^{21}$ Habár a BJP vezéralakja és India akkori miniszterelnöke, Atal Bihari Vajpayee bejelentette, hogy a godrai események nem válhatnak kampánytémává, Modi választási plakátjain (Modi arcképének hátterében egy lángoló vonat) és beszédeiben folyamatosan előbukkantak a merényletre utaló motívumok. ${ }^{22}$ A yatra menetének egy újabb tragédia vetett véget, mivel szeptember 25-én Gudzsarát fővárosában, Gandinagarban két terrorista betört a hívekkel teli hindu Aksardám templomba, és tüzet nyitott a tömegre. A templomon belül foglyokat ejtettek, akiket a rendőrség szabadított ki, miután megostromolták a templomot, és a két terroristát lelőtték. ${ }^{23} \mathrm{Az}$ esetet az indiai pártok terrorcselekménynek minősítették, és egységesen elítélték a több mint 30 halottat és 80 sebesültet maga után hagyó merényletet. ${ }^{24} \mathrm{~A}$ történtekért az egyik legjobban szervezett és legnagyobb iszlám terrorcsoportot, a Lashkare-Taibaát ( „A Tiszták Serege” vagy „Az lgazak Serege”) tették meg felelőssé. Mivel a Lashkar-e-Taiba túlnyomó részt Pakisztán területéről indította meg az akcióit, a kormányzati körökben felmerült a gyanú, hogy a pakisztáni állam is támogatta a szervezett merényletet. Egy kormányzati közlés a két terroristát pakisztáninak nevezte, vagyis nem a terrorszervezet tagjaiként kezelte őket, hanem Pakisztán ügynökeiként. ${ }^{25}$ Végül a két ország közti törékeny béke megőrzése érdekében az indiai kormány nem vizsgálta tovább Pakisztán szerepét, és a hindu közösség elleni terrorista szervezet által végrehajtott provokációnak minősítette az incidenst.

Narendra Modi szeptember 25-én bejelentette, hogy a merényletben elhunytak emléke előtt tisztelegve elhalasztja a hétvégi yatrát, és novemberre vagy decemberre, a választások előtti pár hétre tette a következő alkalmat, hogy ne veszélyeztesse a vallásközösségi feszültség elmérgesedését. ${ }^{26}$ Modi bejelentése ellenére az ellenzéki politikusok teljes mértékben elítélték az Aksardám templomban történt tragédia utáni kampányt, mert szerintük a BJP egyrészt a választási sikerek érdekében felhasználja és átpolitizálja a godrai és a gandinagari tragédiákat, és figyelmen kívül hagyja a társadalmi feszültséget, másrészt a kampánykörúton a saját Hindutva politikájukat Sardar Patel alakjával próbálják meg

21 P. Sood: Cong blames defeat. i. m.

22 V. Gangadhar: Narendra Modi as Sardar Patel. i. m. 14.

23 Cecil Victor: Attack on temple exposes chinks in national security, The Tribune India, 2002. szeptember 29. Forrás: https://www.tribuneindia.com/2002/20020929/edit. htm\#5 (Letöltve: 2020. 10. 15.)

24 Parties flay attack on Akshardham. The Times of India, Ahmedabad, 2002. szeptember 25.

25 Gaurav Yatra politics is out. The Indian Express, Ahmedabad/New Delhi, 2002. szeptember 30.

26 Modi's Gaurav Yatra postponed after attack, The Indian Express, Ahmedabad/New Delhi, 2002. szeptember 25. 
legitimálni. A BJP novemberi és decemberi yatra megmozdulása békésen valósult meg, és legnagyobb sikereit a poszt-godrai vérengzések által sújtott területeken érte el, ami jelzi, hogy elsősorban a hinduk számára próbáltak valamilyen vigaszt nyújtani és megadni számukra a hindu összetartozásból következő szolidaritást.

A Modi-kormányzatnak a vallásközösségi (communal) zavargások alatt tanúsított tehetetlensége miatt indított korrekciós politikai körútja csupán a hindu szavazói kört erősítette meg, de nem hozott társadalmi konszenzust a muszlim kisebbségekkel való békés egymás mellett élés terén. V. Gangadhar nyomán feltételezhetjük, hogy Sardar Patel soha nem adott volna engedélyt hasonló, a hindu identitást erősítő kampányra. Patel munkásságát tekintve a legfontosabb számára az egység és a rend megteremtése volt, amely elvek egyáltalán nem álltak összhangban a Modi-féle politikai irányvonallal. Nem szabad elfelejtenünk, hogy Sardar Patel nem tűrte meg a közösség egységét fenyegető provokatív, radikális és kisebbségellenes szervezeteket vagy megmozdulásokat, ezért alakjának, örökségének felhasználása egy újabb konstruált hagyománnyá vált, főleg ha figyelembe vesszük, hogy a BJP-vel együttműködő VHP, a párt testvérszervezete a yatrák során folyamatosan propagálta a godrai tragédia vallási oldalát. ${ }^{27}$ Sardar Patel nevének repetitív használata és a politikai akciókba való bevonása a Patel-BJP kontinuitás kitalációját akarta elhelyezni a köztudatban. A vallásos jellegü, de lényegében politikai rítusok (yatrák) ismétlődésével Modi egyaránt hagyományt teremtett a kampánymódszer és az emlékezetpolitika terén is. Ez utóbbi számunkra azért lényeges, mert a folytonos utalások Patel múltbéli tetteire egy új legitimációs mezőt hoztak létre, amelyben Modi és más BJP korifeusok megtalálni vélik az aktuális politikai agendához szükséges magyarázatokat. Mint minden új vagy kitalált hagyomány a régiek elhalványulása után a megmaradt ür csak egy részét töltik $\mathrm{ki}^{28}$ vagyis a BJP nem képes egy teljes Patel-narratíva megkonstruálására, ezért az ő interpretációjuk mindig töredezett marad. ${ }^{29}$

27 V. Gangadhar: Narendra Modi as Sardar Patel. i. m. 14.

28 Eric Hobsbawm - Terence Ranger (szerk.): The Invention of Tradition. Cambridge: University Press, 1983. 11.

29 Narendra Modi még a 2014-es választási győzelme előtt bejelentette, hogy Gudzsarát államban megépítteti a világ legmagasabb szobrát Sardar Patel tiszteletére. A munkálatok 2013-ban kezdődtek, és 2018-ban befejeződtek, hogy ünnepélyes keretek között a már miniszterelnök Modi átadja Patel 143-ik születési évfordulóján. A szobor valóban egyedülálló a maga 182 méteres nagyságával. A Patel egész alakos, realista szobra a Statue of Unity (Egység Szobra) nevet kapta, és az indiai nemzet egységének a jelképe. A miniszterelnök második ciklusa alatt és mind a mai napig nagy sajtónyilvánosság előtt ellátogat a szoborhoz Patel születési évfordulóján (október 31.), hogy tisztelettel adózzon a nagy államférfi munkássága előtt, valamint megünnepelje a független indiai nemzet egységét. Narendra Modi ezt a napot 2014-től nemzeti ünnepnek nyilvánította: "Rashtriya Ekta Diwas” (Nemzeti Egység Napja). Az üzenet továbbra is Patel egységesítő törekvéseinek kizsákmányolása, vagyis Modi egy történeti kontinuitást teremtett a Patel által létrehozott nemzeti egység és az általa képviselt egység között. A különbség ugyanakkor az, hogy Patel a muszlim kisebbséget is beemelte ebbe az egységbe, amíg Modi következetesen Indiát a hindu többség nemzetének tartja. 